\title{
Adenosine: an Endogenous Inhibitor of Neutrophil-mediated Injury to Endothelial Cells
}

Bruce N. Cronstein, Richard I. Levin, Jeff Belanoff, Gerald Weissmann, and Rochelle Hirschhorn

Department of Medicine, New York University School of Medicine, New York 10016

\begin{abstract}
Since adenosine and its analogue 2-chloroadenosine prevent neutrophils from generating superoxide anion in response to chemoattractants, we sought to determine whether these agents could inhibit neutrophil-mediated injury of endothelial cells. The chemoattractant $\boldsymbol{N}$-formyl-methionyl-leucyl-phenylalanine (FMLP, $0.1 \mu \mathrm{M}$ ) enhanced the adherence of neutrophils to endothelial cells twofold (18 $\pm 2 \%$ vs. $39 \pm 3 \%$ adherence, $P<0.001)$ and caused substantial neutrophil-mediated injury to endothelial cells $(2 \pm 2 \%$ vs. $39 \pm 4 \%$ cytotoxicity, $P<0.001)$. 2-Chloroadenosine (10 $\mu \mathrm{M})$ not only inhibited the adherence of stimulated neutrophils by $60 \%(24 \pm 2 \%$ adherence, $P<0.001)$ but also diminished the cytotoxicity by $51 \%(20 \pm 4 \%$ cytotoxicity, $P$ $<0.002)$. Furthermore, depletion of endogenously released adenosine from the medium by adenosine deaminase-enhanced injury to endothelial cells by stimulated neutrophils (from $39 \pm 4 \%$ to $69 \pm 3 \%$ cytotoxicity, $P<0.001$ ). Indeed, in the presence of adenosine deaminase, even unstimulated neutrophils injured endothelial cells (19 $\pm 4 \%$ vs. $2 \pm 2 \%$ cytotoxicity, $P<0.001)$. These data indicate that engagement of adenosine receptors prevents both the adhesion of neutrophils and the injury they cause to endothelial cells. Adenosine inhibits injury provoked not only by cells that have been stimulated by chemoattractants but also by unstimulated cells. Based on this model of acute vascular damage we suggest that adenosine is not only a potent vasodilator, but plays the additional role of protecting vascular endothelium from damage by neutrophils.
\end{abstract}

\section{Introduction}

During inflammation activated neutrophils migrate in a directed fashion and become "sticky." They adhere to other neutrophils (cell-cell aggregation) and endothelial cells, release their lysosomal enzymes, and generate toxic oxygen metabolites (1). A variety of agents can stimulate neutrophils to adhere to endothelial cells (2-4), and some of these agents can also provoke neutrophils to injure endothelial cells (5-8). Vascular endothelial cells are injured by toxic oxygen metabolites released by activated neutrophils (5-8), whereas endothelial cells are detached from their underlying matrix by lysosomal enzymes extruded by neutrophils (9). We have recently observed that adenosine, a potent autacoid released from various tissues (10), inhibited superoxide

This material has been presented in part at the 1985 meeting of the American Society for Clinical Investigation. 1986.

Received for publication 1 October 1985 and in revised form 9 May

J. Clin. Invest.

(C) The American Society for Clinical Investigation, Inc. 0021-9738/86/09/0760/11 \$1.00

Volume 78, September 1986, 760-770 anion and $\mathrm{H}_{2} \mathrm{O}_{2}$ release from stimulated neutrophils by engaging specific adenosine $A_{2}$ receptors at their surface (11-13). In contrast, adenosine did not affect either aggregation of neutrophils or release of lysosomal enzymes from neutrophils (11). Others have confirmed these observations (14).

Because adenosine is, therefore, a potential anti-inflammatory agent of endogenous origin, released by, for example, endothelial cells, we have determined that spontaneously released adenosine affects the ability of human neutrophils to kill endothelial cells. We have also studied the effects on neutrophilendothelial cell interactions of 2-chloroadenosine, a potent, poorly metabolized agonist at adenosine receptors. Data from these experiments show that both endogenously released adenosine and 2-chloroadenosine protect endothelial cells from injury by neutrophils.

\section{Methods}

Materials. 2-Chloroadenosine, hypoxanthine, inosine, adenosine deaminase [type VIII, suspension in $3.2 \mathrm{M}\left(\mathrm{NH}_{4}\right)_{2} \mathrm{SO}_{4}$ ], Medium 199 (powdered), xanthine oxidase (grade III), and bovine serum albumin (BSA) (Cohn fraction V) were obtained from Sigma Chemical Co. (St. Louis, MO). $N$-Formyl-methionyl-leucyl-phenylalanine (FMLP) ${ }^{1}$ was obtained from Vega Biochemicals (Tucson, AZ). Collagenase (type I) was purchased from Worthington Diagnostics (Freehold, NJ). 2'-Deoxycoformycin was a generous gift from Dr. John Douros (National Cancer Institute, Bethesda, MD). Tissue culture medium RPMI 1640 was obtained from Gibco Laboratories (Chagrin Falls, $\mathrm{OH}$ ). Catalase was purchased from Calbiochem-Behring Corp. (La Jolla, CA). ${ }^{51} \mathrm{Cr}$ (sodium chromate) was obtained from New England Nuclear (Boston, MA).

Human umbilical vein endothelial cells. Human umbilical vein endothelial cells were obtained by collagenase treatment of fresh human umbilical cords and grown to confluence in Medium 199/human serum $(20 \%)$ at $37^{\circ} \mathrm{C}$ in a $\mathrm{CO}_{2}(5 \%)$ atmosphere (15). Briefly, sterile umbilical cords were kept in buffered saline solution until use. A section of umbilical vein $(20 \mathrm{~cm}$ minimum) that was not damaged by clamps was cannulated, washed with medium, and then incubated with $10 \mathrm{ml}$ of collagenase $(0.1 \%)$ at $37^{\circ} \mathrm{C}$ for 15 minutes. The endothelial cells were then collected, washed, and placed in a gelatin-coated $75-\mathrm{cm}^{2}$ tissue culture flask in Medium 199/human serum (20\%). The cells were then incubated for 2$3 \mathrm{~d}$ at $37^{\circ} \mathrm{C}$ in a $\mathrm{CO}_{2}(5 \%)$ atmosphere, passed as necessary, and removed from the gelatin by collagenase treatment. $10 \mathrm{ml}$ of collagenase $(0.2 \%)$ was added to the flasks and the flasks were incubated at $37^{\circ} \mathrm{C}$ for 15 $\mathrm{min}$. The cells were collected, centrifuged, and washed before being layered onto 24-well tissue culture plates. Cells were grown to confluence at $37^{\circ} \mathrm{C}$ in a $\mathrm{CO}_{2}(5 \%)$ atmosphere.

Labeling of endothelial cells with ${ }^{51} \mathrm{Cr}$. For experiments involving ${ }^{51} \mathrm{Cr}$ release, the endothelial cells were incubated with ${ }^{51} \mathrm{Cr}$ (sodium chromate) in medium ( $5 \mu \mathrm{Ci} / \mathrm{ml})$ for $2 \mathrm{~h}$ and washed twice before use (5). The endothelial cells took up 3-10\% of the label $(6,000-20,000 \mathrm{cpm})$.

Human neutrophils. Human neutrophils were isolated from whole blood after centrifugation through hypaque-ficoll gradients, sedimentation

1. Abbreviations used in this paper: FMLP, $N$-formyl-methionyl-leucylphenylalanine. 
through dextran (6\%, wt/vol), and hypotonic lysis of red blood cells (16). This procedure allows study of populations that are $98 \pm 2 \%$ neutrophils with few contaminating erythrocytes or platelets. In brief, fresh whole blood was layered over ficoll-hypaque and centrifuged $(1,000 \mathrm{~g}, 45 \mathrm{~min})$ at room temperature. The red cell pellet at the bottom of the gradient was collected and diluted with an equal volume of phosphate-buffered saline (PBS). A volume of dextran in normal saline equivalent to 20 $30 \%$ of the volume of the diluted red cells was added and the red cells were permitted to sediment to $\sim 50 \%$ of the final volume. The supernate was collected and centrifuged at $700 \mathrm{~g}$ for $8 \mathrm{~min}$. The pellet of neutrophils was resuspended in one volume of PBS and incubated with 3 vol of water ( $40 \mathrm{~s})$, and the incubation terminated by addition of 1 vol of $3.6 \%$ saline. The remaining neutrophils were then pelleted and washed twice in PBS and resuspended $\left(50 \times 10^{6} / \mathrm{ml}\right)$ in medium supplemented with BSA $(0.2 \%$, wt/vol).

Labeling of neutrophils with ${ }^{51} \mathrm{Cr}$. For experiments to determine adherence neutrophils were labeled with ${ }^{51} \mathrm{Cr}$ by a variation on the method of Gallin et al. (17). In brief, neutrophils $\left(24 \times 10^{6} / \mathrm{ml}\right)$ were incubated with ${ }^{51} \mathrm{Cr}(24 \mu \mathrm{Ci} / \mathrm{ml})$ in RPMI $1640 / 0.2 \%$ BSA with constant gentle rocking for $1 \mathrm{~h}$ at $37^{\circ} \mathrm{C}$. The cells were then pelleted and washed three times in RPMI before suspension in RPMI 1640/0.2\% BSA (25 $\times 10^{6} / \mathrm{ml}$ ).

Endothelial cell toxicity assays. Neutrophils were added to cultures of endothelial cells at a final concentration of $10 \times 10^{6} / \mathrm{ml}(10: 1 \mathrm{neu}-$ trophils/endothelial cells) in Medium 199/BSA (0.2\%). In some wells neutrophils were stimulated with FMLP $(0.1 \mu \mathrm{M}$ final concentration $)$ in the presence or absence of 2 -chloroadenosine ( $10 \mu \mathrm{M}$ final concentration). The cultures were then incubated for $90 \mathrm{~min}$ at $37^{\circ} \mathrm{C}$ in a $5 \% \mathrm{CO}_{2}$ atmosphere, gently washed twice, and examined with an inverted phasecontrast microscope. The adherent endothelial cells were counted using a technique that permits representative sampling of endothelial cell monolayers. Briefly, the undersurface of culture wells was marked using a template which allowed counting of similar sites in all wells. Endothelial cells were then counted in situ in two areas per well before and after incubation for $90 \mathrm{~min}$ with stimulated and unstimulated neutrophils in the presence or absence of 2-chloroadenosine. Cell counts obtained by this method were compared to cell counts obtained by hemocytometer and automated cell counter. To count cells by either hemocytometer or Coulter counter (Coulter Electronics, Inc., Hialeah, CA) the endothelial cells were harvested after incubation with collagenase $(0.1 \%)$. The cells were then pelleted and resuspended in Medium 199, and an aliquot was counted in a hemocytometer or, after dilution with Isoton, counted in a Coulter counter. Cell counts obtained in situ correlated well with those obtained by hemocytometer $(r=0.99, P<0.001$, Fig. 1$)$ and Coulter counter $(r=0.95, P<0.001$, Fig. 1). Endothelial cell toxicity varied with both the neutrophil donor and the endothelial cell line.

For those experiments in which release of ${ }^{51} \mathrm{Cr}$ was used as an indicator of endothelial cell toxicity, the following procedure was used. Labeled endothelial cells were incubated with neutrophils and other agents for 90 min at $37^{\circ} \mathrm{C}$ in a $5 \% \mathrm{CO}_{2}$ atmosphere and the supernates were collected (5). Medium 199/BSA (0.2\%) and RPMI 1640/BSA (0.2\%) were used as the incubation media in these experiments, and are referred to as Medium 199 and RPMI, respectively. The medium used for each group of experiments is indicated. The adherent endothelial cells were collected after treatment with collagenase $(0.2 \%)$ or, in some experiments, Triton $\mathrm{X}-100(2 \%, \mathrm{vol} / \mathrm{vol})$. Supernates and endothelial cells were counted in a gamma counter and percent release was calculated by use of the following formula: $\left[\mathrm{cpm}_{\text {supernate }} /\left(\mathrm{cpm}_{\text {supernate }}+\mathrm{cpm}_{\text {endothelial cells }}\right)\right] \times 100$.

In some experiments supernates were spun at $1,000 \mathrm{rpm}$ for $10 \mathrm{~min}$, the cell-free supernate was collected and counted, and the remaining cell pellet was counted separately. Percent cytotoxicity was calculated for each sample, in each experiment, by the following formula: $\%{ }^{51} \mathrm{Cr}$ release $_{\text {exp }}-\%{ }^{51} \mathrm{Cr}$ release control $_{\text {. }}$.

Mean spontaneous release of ${ }^{51} \mathrm{Cr}$ from endothelial cells incubated in Medium 199/0.2\% BSA in all experiments was $23 \pm 2 \%(n=18)$ and from endothelial cells incubated in RPMI was $18 \pm 1 \%(n=12)$. In preliminary experiments, cytotoxicity could be demonstrated by $30 \mathrm{~min}$ of incubation, reached a maximum by $90 \mathrm{~min}$, and remained constant for
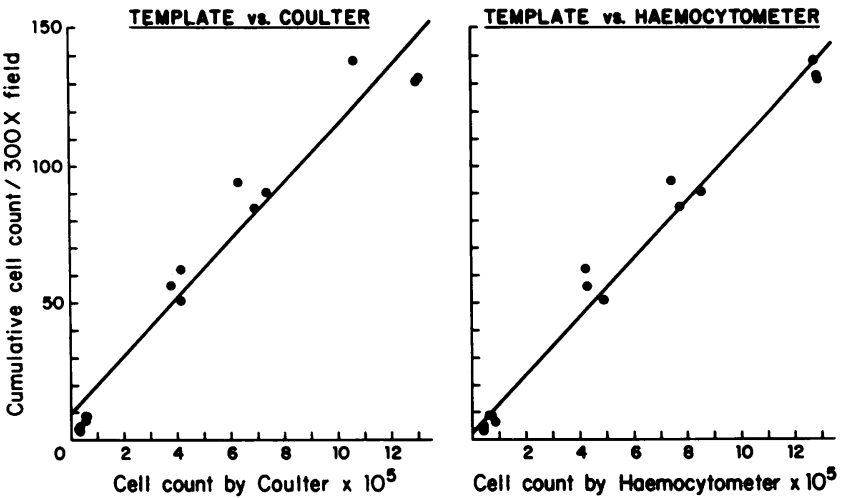

Figure 1. Correlation of in situ cell counts with automated and hemocytometer cell counts. The graph on the left shows the linear relationship between in situ counts (template method) and automated counting by Coulter counter. The cells were counted as described. The relationship is described by the equation: Template count $=\mathbf{( 0 . 0 0 0 1 0 1}$ $\times$ Coulter count $)+10.6$. The standard error of the estimate was 17.04, $r=0.95, P<0.001$. The graph on the right shows the linear relationship between cell counts in situ (template) and counts obtained by hemocytometer. The relationship is described by the equation: Template count $=(0.000105 \times$ hemocytomer count $)+3.1$. The standard error of the estimate was 17.19, $r=0.99, P<0.001$.

as long as $180 \mathrm{~min}$. Therefore all determinations of cytotoxicity were performed after incubation for $90 \mathrm{~min}$ at $37^{\circ} \mathrm{C}$ in a $5 \% \mathrm{CO}_{2}$ atmosphere. Endothelial cell toxicity varied with both the neutrophil donor and the endothelial cell line.

Examination of supernates for the presence of intact endothelial cells. Supernates of endothelial cell cultures were aspirated after incubation with neutrophils for $90 \mathrm{~min}$ at $37^{\circ} \mathrm{C}$. The remaining adherent cells were washed once with medium and the wash combined with the supernate. In some experiments supernates were stained directly with Giemsa stain and suspended cells counted in a hemocytometer. In other experiments an aliquot of supernates was spun onto a microscope slide in a cytocentrifuge at $\mathbf{3 0 0} \mathrm{rpm}$ (Rainin Instrument Co., Boston, MA) and stained with Wright's stain, and the total number of endothelial cells present was counted. Endothelial cells were easily distinguished from neutrophils on the basis of their large size, uniform or vacuolated cytoplasm, and absence of cytoplasmic granules and large ovoid nuclei (Fig. 2). The percentage of endothelial cells present was determined after counting 400 cells.

Preparation of enzymes for use in endothelial cell toxicity assays. Adenosine deaminase and xanthine oxidase were dialyzed against PBS for at least $6 \mathrm{~h}$ at $4^{\circ} \mathrm{C}$ before dilution in medium. In some experiments adenosine deaminase $(2.5 \mathrm{IU} / \mathrm{ml})$ was incubated with deoxycoformycin $(10 \mu \mathrm{M})$ for $30 \mathrm{~min}$ at room temperature. The final concentration of preincubated adenosine deaminase was $0.25 \mathrm{IU} / \mathrm{ml}$ in these experiments.

Adherence of neutrophils to endothelial cells. Adherence of neutrophils to endothelial cells was assayed, essentially as described by Diener et al. (18). Briefly, confluent monolayers of endothelial cells were grown in 16-mm diam tissue culture wells and were washed twice with medium. ${ }^{51} \mathrm{Cr}$-labeled neutrophils were layered over endothelial cell monolayers in the presence or absence of 2-chloroadenosine $(10 \mu \mathrm{M})$ and FMLP $(0.1 \mu \mathrm{M})$ in a final volume of $0.5 \mathrm{ml}$. After incubation periods of $15-30$ min at $37^{\circ} \mathrm{C}$ in a $5 \% \mathrm{CO}_{2}$ atmosphere, the supernatant was collected, the monolayers were washed once with medium, and the wash was added to the supernate. All wells were examined microscopically to determine whether loss of endothelial cells had occurred during incubation or washing. The remaining endothelial cells and adherent ${ }^{51} \mathrm{Cr}$-labeled neutrophils were lysed by the addition of $0.5 \mathrm{ml}$ of $\mathrm{NH}_{4} \mathrm{OH}(1.5 \mathrm{M})$ to each well followed by incubation overnight at room temperature (19). The lysed endothelial cells and neutrophils were then collected and the radioactivity of both the supernates and lysed cells was determined by 


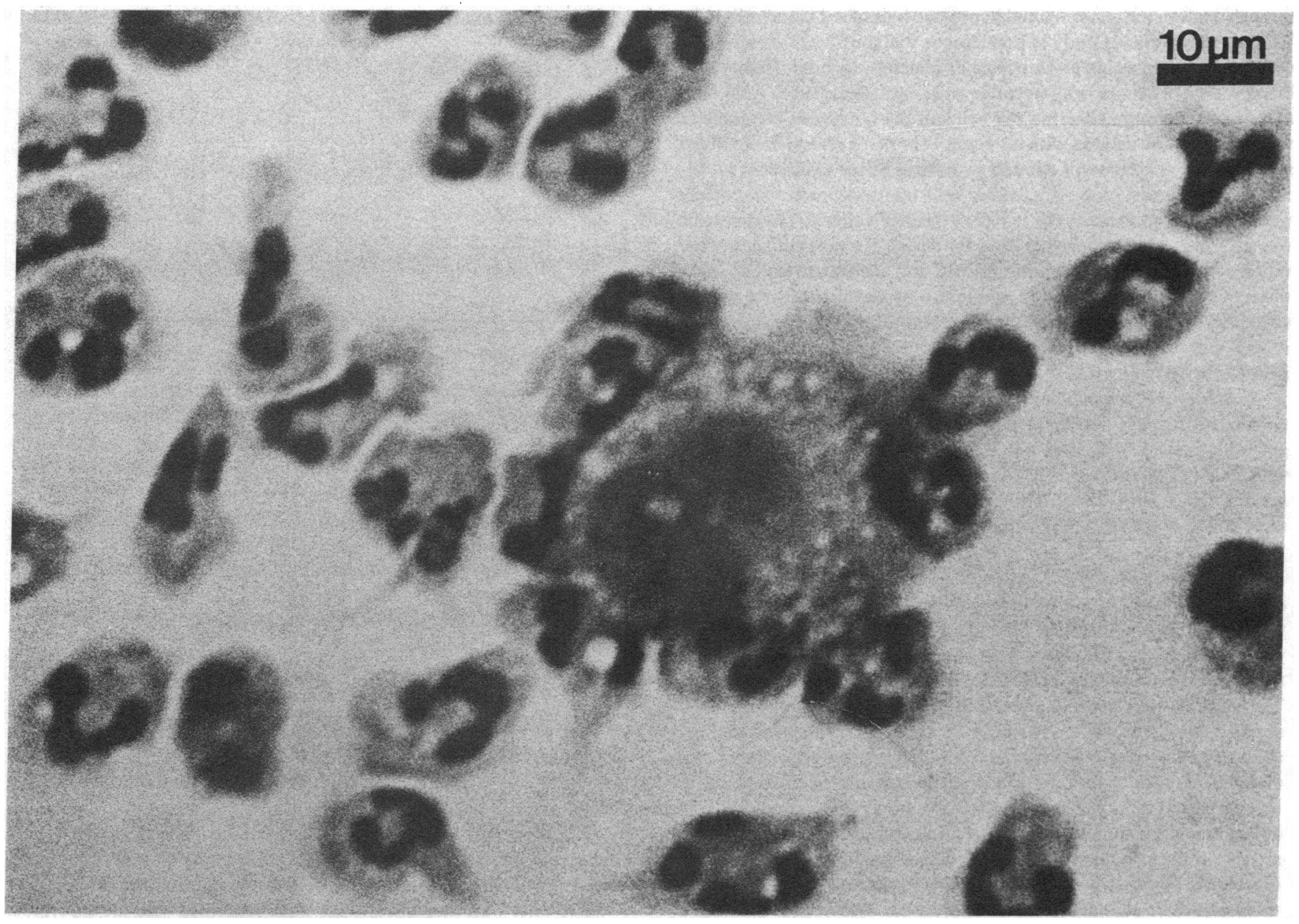

Figure 2. Photomicrograph of an endothelial cell and neutrophils in supernatant medium of endothelial cell monolayers after incubation with stimulated neutrophils. Confluent endothelial cells were incubated in RPMI 1640 with neutrophils (10:1 neutrophils/endothelial cells) in the presence of FMLP for $90 \mathrm{~min}$ at $37^{\circ} \mathrm{C}$ in a $5 \% \mathrm{CO}_{2}$ atmo-

counting in a gamma counter. Percent adherence was calculated by the following formula:

$$
\left[\mathrm{cpm}_{\text {lyed cells }} /\left(\mathrm{cpm}_{\text {supernate }}+\mathrm{cpm}_{\text {lyood cellas }}\right)\right] \times 100 \text {. }
$$

Analysis of supernates of endothelial cell cultures by reverse-phase high-pressure liquid chromatography. Endothelial cell cultures were washed twice and overlaid with fresh medium. Neutrophils and various agents were added and aliquots of the supernatants were collected after incubation for $0-30 \mathrm{~min}$ at $37^{\circ} \mathrm{C}$. These aliquots were kept frozen at $-70^{\circ} \mathrm{C}$ until analysis could be performed. Proteins were precipitated with $2 \mathrm{~N}$ perchloric acid, the $\mathrm{pH}$ was readjusted to 7.0 with $2.2 \mathrm{~N} \mathrm{KOH}$, and the samples were centrifuged in an Eppendorf microfuge for $5 \mathrm{~min}$ at $4^{\circ} \mathrm{C}(10,000 \mathrm{~g})$ to eliminate the precipitated proteins. Adenosine concentrations were determined by reverse-phase high-pressure liquid chromatography as previously described (20). The samples were applied to a C18 $\mu$ Bondapack column (Waters Associates, Inc., Milford, MA) and eluted with a $0-40 \%$ linear gradient (formed over $60 \mathrm{~min}$ ) of $0.01 \mathrm{M}$ ammonium phosphate (pH 5.5) and methanol, with a $1.5 \mathrm{ml} / \mathrm{min}$ flow rate. The adenosine peak was identified by retention time, the characteristic 250/260 UV absorbance ratio of adenosine, and disappearance of the peak after treatment with adenosine deaminase $(0.25 \mathrm{IU} / \mathrm{ml})$. Concentrations were determined by comparison of absorption at $\mathbf{2 6 0}$ nM to standards. sphere. The supernatant medium was aspirated and the well was washed twice with medium. The wash was then combined with the aspirated supernate and an aliquot of the resulting suspension was spun onto a microscope slide in a cytocentrifuge at $300 \mathrm{rpm}$. The cells were then stained with Wright's stain.

Concentrations of reagents. Unless otherwise indicated, the final concentrations of reagents used in these experiments were FMLP $(0.1 \mu \mathrm{M})$, 2-chloroadenosine $(10 \mu \mathrm{M})$, adenosine deaminase $(0.25 \mathrm{IU} / \mathrm{ml})$, and catalase $(1,200 \mathrm{U} / \mathrm{ml})$. The media used in these experiments were supplemented with $0.2 \%$ BSA.

Statistical analysis. The statistical significance of differences between the means of multiple sample populations was examined by use of oneway analysis of variance. Student's $t$ test was used to compare differences between two sample populations. The values reported for ${ }^{51} \mathrm{Cr}$ release are the means and standard errors of 9-18 replicates obtained in three to five separate experiments utilizing cells from different donors except for those experiments involving the effects of deoxycoformycin and inosine $(n=6$ in separate experiments utilizing cells from two different donors). The values reported for adherence are the means and standard errors of 17-24 replicates obtained in six separate experiments utilizing the neutrophils of different donors and different endothelial cell lines.

\section{Results}

Effect of 2-chloroadenosine on adherence of neutrophils to endothelial cells. A small proportion of resting neutrophils adhere to endothelial cells (Table I). The surrogate bacterial chemoattractant FMLP stimulates more than a twofold increase in ad- 
Table I. 2-Chloroadenosine (10 $\mu$ M) Prevents Adherence of Activated Neutrophils to Endothelial Cells

\begin{tabular}{ll}
\hline Condition & \% adherence \\
\hline Neutrophils & $18 \pm 2$ \\
Neutrophils + FMLP & $39 \pm 3$ \\
Neutrophils + 2-chloroadenosine & $19 \pm 3$ \\
Neutrophils + FMLP +2-chloroadenosine & $24 \pm 2$ \\
\hline
\end{tabular}

${ }^{51} \mathrm{Cr}$-labeled neutrophils $\left(5 \times 10^{6} / \mathrm{ml}\right)$ were layered onto confluent monolayers of umbilical vein endothelial cells in the presence of medium alone or FMLP with or without 2-chloroadenosine in 16-mm diam wells in a final volume of $0.5 \mathrm{ml}$ (five neutrophils/endothelial cell). The cells were incubated for $30 \mathrm{~min}$ at $37^{\circ} \mathrm{C}$ in a $5 \% \mathrm{CO}_{2}$ atmosphere. The supernates and adherent cells were collected, the radioactivity quantitated and percent adherence calculated as described. With the exception of experiments designed to determine whether 2-chloroadenosine inhibits adherence of unstimulated neutrophils to endothelial cells $(n=6)$ these results represent the means and standard errors of 17-24 replicates obtained in six separate experiments using neutrophils from different donors and different endothelial cell lines.

herence of neutrophils to endothelial cells $(P<0.001)$. Although 2-chloroadenosine $(10 \mu \mathrm{M})$ does not affect adherence of unstimulated neutrophils to endothelial cells 2-chloroadenosine diminishes adherence of stimulated neutrophils to endothelial cells $(P<0.001)$.

2-Chloroadenosine inhibits adherence via an effect on neutrophils. 2-Chloroadenosine could inhibit adherence of neutrophils to endothelial cells by affecting either the endothelial cells or the neutrophils. We therefore determined whether preincubation of endothelial cells with 2-chloroadenosine interfered with adherence of stimulated or resting neutrophils to endothelial cells. Preincubation of endothelial cells with 2-chloroadenosine altered neither adherence of resting or stimulated neutrophils nor inhibition of adherence by 2-chloroadenosine (Table II). These results suggested that 2-chloroadenosine diminished adherence of neutrophils to endothelial cells by acting upon the neutrophils.

Effect of 2-chloroadenosine on endothelial cell toxicity mediated by activated neutrophils. Unstimulated neutrophils caused only minor loss of endothelial cells from their gelatin matrix after $90 \mathrm{~min}$ of incubation at $37^{\circ} \mathrm{C}$ (Fig. 3). In contrast, neutrophils activated by FMLP caused marked loss of adherent endothelial cells from the matrix. 2-Chloroadenosine, at a concentration which maximally inhibits neutrophil function $(10 \mu \mathrm{M}$, 12), prevented this disappearance of endothelial cells (Fig. 3). To quantitate these findings, the number of adherent endothelial cells in a defined area was counted in situ before and after incubation with neutrophils. Unstimulated neutrophils did not diminish the number of endothelial cells remaining adherent to gelatin coated plastic plates ( $104 \pm 7$ vs. $107 \pm 5$ cells/site, $n=6$ sites, before and after incubation, respectively). In contrast, activated neutrophils $(0.1 \mu \mathrm{M}$ FMLP) significantly reduced the number of adherent endothelial cells $(94 \pm 4$ vs. $62 \pm 8$ cells/site, $n=6$ sites, $P<0.005)$. 2-Chloroadenosine $(10 \mu \mathrm{M})$ prevented activated neutrophils from provoking loss of endothelial cells from their substratum ( $108 \pm 4$ vs. $108 \pm 6$ cells/site, $n=4$ sites).

Endothelial cells may disappear from tissue culture wells because they are lysed or because they are detached from their matrix by activated neutrophils (5-9). To distinguish between
Table II. Preincubation of Endothelial Cells with 2-Chloroadenosine Does Not Affect Adherence of Neutrophils to Endothelial Cells

\begin{tabular}{lll}
\hline & Preincubation & \\
\cline { 2 - 3 } Condition & 2-Chloroadenosine & Medium \\
\hline & $\%$ adherence & $\%$ adherence \\
Neutrophils & $26 \pm 5$ & $24 \pm 5$ \\
Neutrophils + FMLP & $48 \pm 5$ & $43 \pm 7$ \\
Neutrophils + FMLP & & $32 \pm 4$ \\
+2-Chloroadenosine & $31 \pm 3$ & \\
\hline
\end{tabular}

Endothelial cells were incubated with Medium 199/20\% fetal calf serum for $1 \mathrm{~h}$ at $37^{\circ} \mathrm{C}$ in a $5 \% \mathrm{CO}_{2}$ atmosphere in the presence and absence of 2-chloroadenosine. The monolayers were washed three times and ${ }^{51} \mathrm{Cr}$-labeled neutrophils $\left(5 \times 10^{6} / \mathrm{ml}\right)$ were then layered onto the monolayers in $16-\mathrm{mm}$ diam tissue culture wells. The cells were then incubated in the presence or absence of FMLP with or without 2-chloroadenosine and adherence determined as described. These results are the means and standard errors of six replicates obtained using neutrophils from two different donors and different endothelial cell lines. The data was analyzed by means of two-way analysis of variance. Results obtained did not vary significantly because of preincubation of endothelial cells with 2-chloroadenosine; nor did preincubation with 2-chloroadenosine influence the differences among the various conditions. The adherence of neutrophils to endothelial cells did vary significantly depending on stimulation and the presence of 2-chloroadenosine $(P<0.001)$.

these possibilities, supernates of endothelial cell cultures were examined microscopically for the presence and number of endothelial cells (Fig. 2). After incubation of endothelial cell monolayers with unstimulated neutrophils only $1 \%$ (range 0 $2 \%$ ) of the cells present in the supernate were endothelial cells. After incubation with stimulated neutrophils the percentage of endothelial cells present did not change (range 0-2\%). The number of endothelial cells present in these supernates $(0-4,000)$ accounted for $1 \%$ or less of the total number of endothelial cells attached to tissue culture wells. Thus, activated neutrophils provoke disappearance of adherent endothelial cells from tissue culture wells primarily by lysing the cells.

Quantitation of ${ }^{51} \mathrm{Cr}$ release from labeled endothelial cells as a measure of endothelial cell toxicity. To quantitate endothelial cell injury by neutrophils, ${ }^{51} \mathrm{Cr}$ release was determined from prelabeled endothelial cells after incubation with neutrophils. Because ${ }^{51} \mathrm{Cr}$ found in supernates of labeled endothelial cell cultures may represent either detached endothelial cells or ${ }^{51} \mathrm{Cr}$ released from dying cells, cell-associated and soluble ${ }^{51} \mathrm{Cr}$ was quantified in supernates of endothelial cell cultures incubated alone or with neutrophils. Only $6 \%$ of ${ }^{51} \mathrm{Cr}$ in the supernatant was cell associated when endothelial cells were incubated alone (Table III). Incubation of endothelial cells with unstimulated neutrophils led to greater apparent detachment of endothelial cells in that cell-associated ${ }^{51} \mathrm{Cr}$ increased in supernates. In contrast, stimulated neutrophils preferentially provoked release of soluble ${ }^{51} \mathrm{Cr}$ from labeled endothelial cells. We had previously found that $<2 \%$ of the cells present in supernates were endothelial cells; therefore we did not separate cell-associated ${ }^{51} \mathrm{Cr}$ from soluble ${ }^{51} \mathrm{Cr}$ in subsequent experiments.

Neutrophils injure endothelial cells by secretion of toxic oxygen metabolites. Several laboratories have reported that stim- 


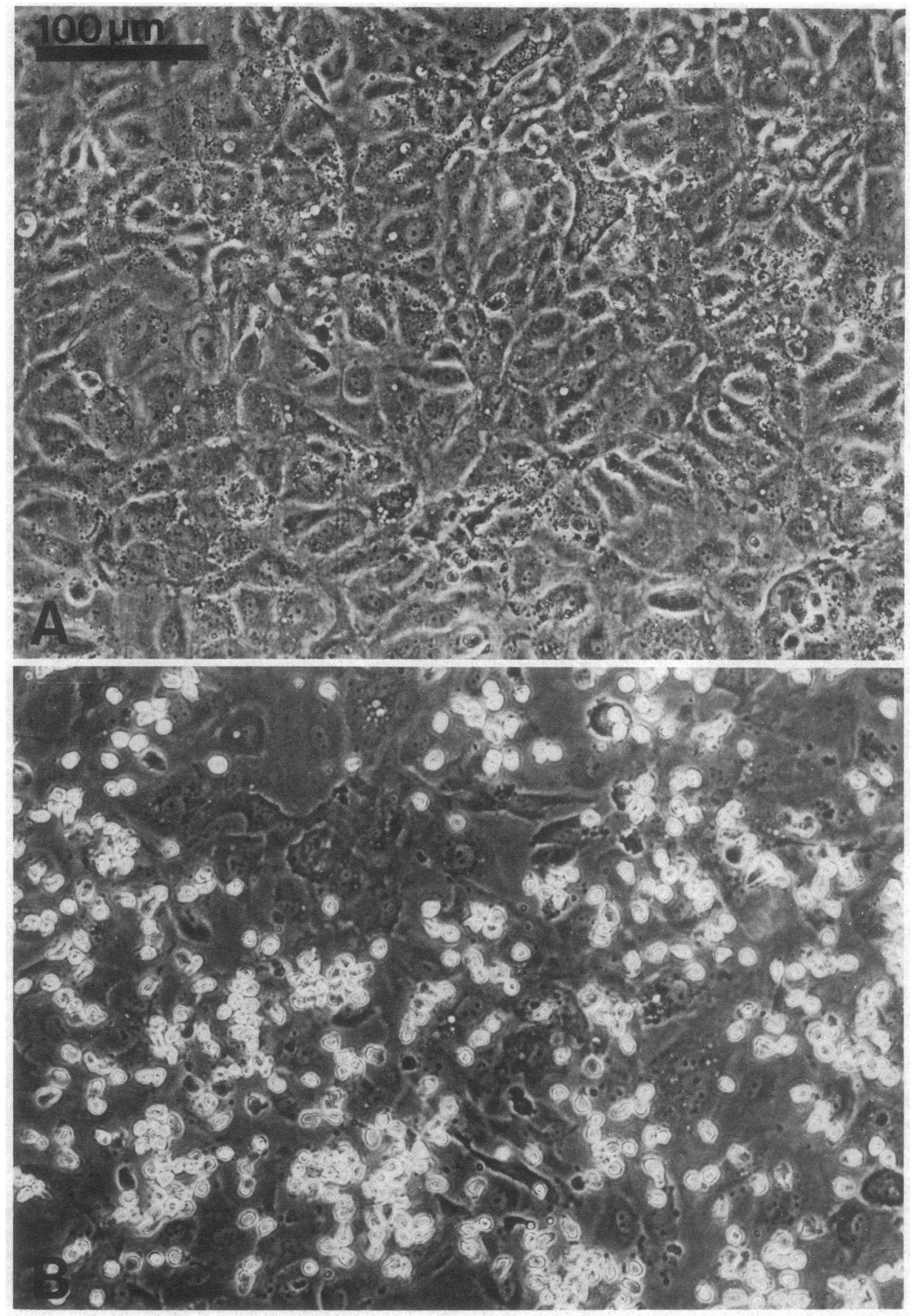




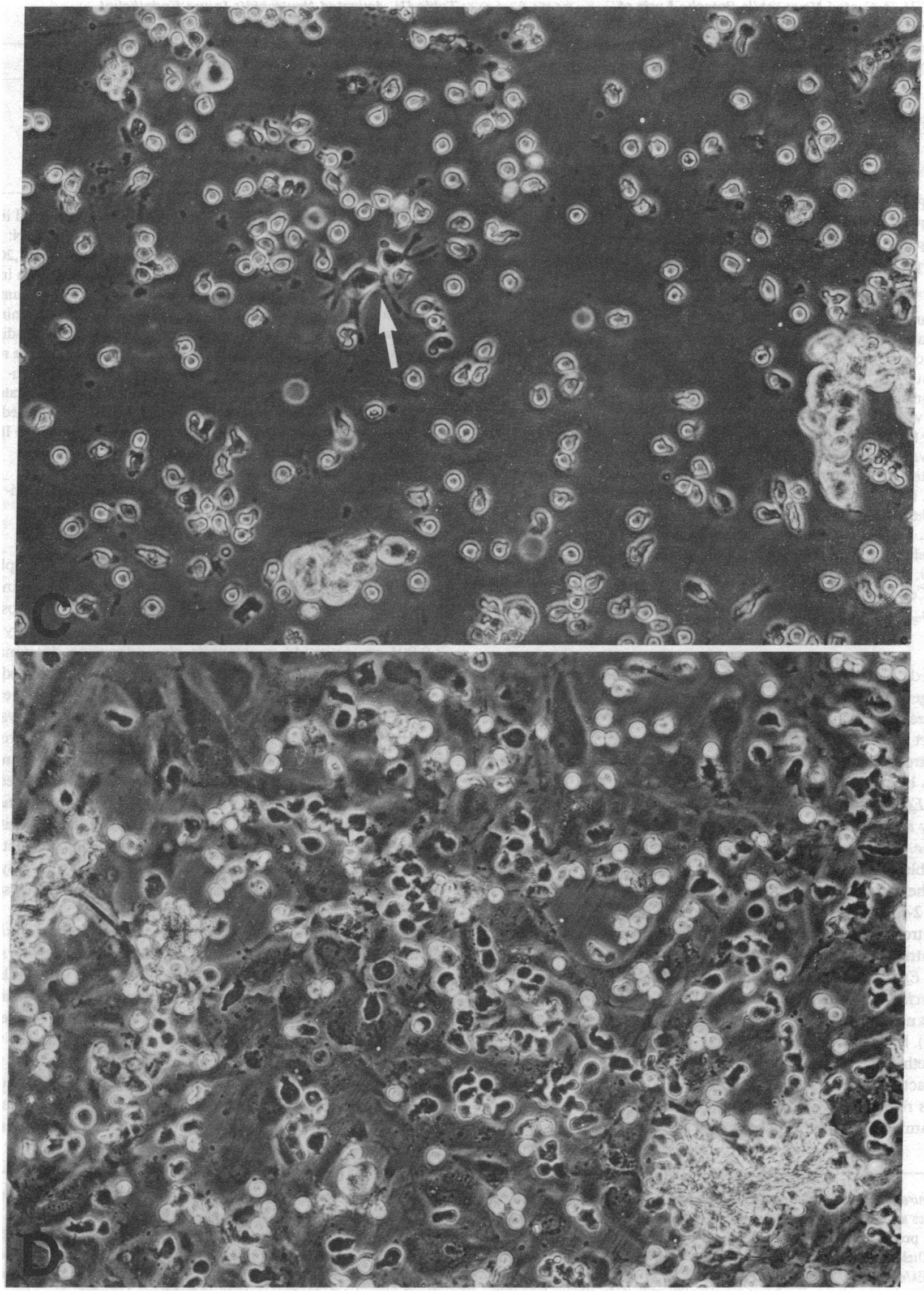


Table III. Activated Neutrophils Provoke Lysis of

Endothelial Cells: Determination of Soluble and

"Cell-associated" ${ }^{51} \mathrm{Cr}$ in Supernates of Endothelial Cells

\begin{tabular}{llll}
\hline & \multicolumn{2}{l}{${ }^{\text {S1 Cr in supernates }}$} & \\
\cline { 2 - 3 } Condition & Cell-associated & Soluble & \% cell-associated* \\
\hline & $c p m$ & $c p m$ & \\
EC & $73 \pm 7$ & $804 \pm 211$ & $6 \pm 2$ \\
EC + PMN & $158 \pm 16$ & $629 \pm 60$ & $20 \pm 2$ \\
EC + PMN + FMLP & $272 \pm 36$ & $2,743 \pm 424$ & $9 \pm 0.2$ \\
$\begin{array}{llll}\text { EC + PMN + FMLP } \\
+ \text { ClA }\end{array}$ & & & \\
& $186 \pm 59$ & $893 \pm 118$ & $17 \pm 1$ \\
\hline
\end{tabular}

Confluent cultures of ${ }^{51} \mathrm{Cr}$-labeled endothelial cells were incubated in Medium 199/0.2\% BSA alone or with neutrophils in the presence or absence of FMLP $(0.1 \mu \mathrm{M})$ and 2-chloroadenosine $(10 \mu \mathrm{M})$ for 90 $\min$ at $37^{\circ} \mathrm{C}$. At the end of incubation supernates were collected and the remaining endothelial cell monolayers washed with medium. The wash was then combined with the aspirated supernate and spun at $800 \mathrm{~g}$ for $10 \mathrm{~min}$ at room temperature. The cell-free supernate (soluble) was aspirated and counted separately from the cell pellet (cell-associated). These results are the mean and standard error of three replicates. Mean counts per well recovered in this experiment were $6,185 \pm 153 \mathrm{cpm}$. Similar results were obtained in a separate experiment. Abbreviations: ClA, 2-chloroadenosine $(10 \mu \mathrm{M})$; EC, endothelial cells; FMLP, $N$-formyl-methionyl-leucyl-phenylalanine $(0.1 \mu \mathrm{M})$; PMN, neutrophils.

* \% Cell associated was calculated by the following formula: $\left[\mathrm{cpm}_{\text {cell anocirted }} /\left(\mathrm{cpm}_{\text {cell anocirtod }}+\mathrm{cpm}_{\text {soluble }}\right)\right] \times 100$.

ulated neutrophils injure endothelial cells by elaboration of toxic oxygen metabolites (5-8). To confirm that stimulated neutrophils injure endothelial cells via release of $\mathrm{H}_{2} \mathrm{O}_{2}$, we examined the effect of catalase on endothelial cell injury due to stimulated neutrophils. Catalase essentially reversed damage to endothelial cells by stimulated neutrophils (Table IV).

Effect of 2-chloroadenosine $(10 \mu M)$ on endothelial cell toxicity mediated by activated neutrophils as measured by ${ }^{51} \mathrm{Cr}$ release. Unstimulated neutrophils did not injure endothelial cells (Table V). Neutrophils exposed to FMLP, however, injured endothelial cells $(P<0.001$ vs. unstimulated neutrophils, Table V). 2-Chloroadenosine partially reversed the effects of activated neutrophils on cultured endothelial cells $(P<0.002$ vs. activated neutrophils).

Effect of exogenous adenosine deaminase on endothelial cell toxicity due to activated neutrophils. We have previously reported that neutrophils release adenosine into their supernatant medium (11). Endothelial cells also release adenosine (21). To determine whether endogenously released adenosine could affect the ability of activated neutrophils to injure endothelial cells, adenosine was removed by addition of adenosine deaminase. Adenosine deaminase dramatically enhanced endothelial cell injury caused
Table IV. Activated Neutrophils Injure Endothelial Cells by Secretion of Toxic Oxygen Products

\begin{tabular}{ll}
\hline Condition & \% cytotoxicity \\
\hline PMN & $19 \pm 4$ \\
PMN + FMLP & $32 \pm 5^{*}$ \\
PMN + FMLP + catalase & $16 \pm 3 \ddagger$ \\
PMN + FMLP + boiled catalase & $35 \pm 4 \S$ \\
\hline
\end{tabular}

Confluent cultures of ${ }^{51} \mathrm{Cr}$-labeled endothelial cells were incubated in RPMI 1640/BSA $(0.2 \%)$ with neutrophils $\left(10 \times 10^{6} / \mathrm{ml}, 10: 1 \mathrm{PMN}\right.$ : EC) in the presence or absence of FMLP $(0.1 \mu \mathrm{M})$ and catalase $(1,200$ $\mathrm{U} / \mathrm{ml}$ ) for $90 \mathrm{~min}$ at $37^{\circ} \mathrm{C}$. In some wells catalase which had been immersed for $10 \mathrm{~min}$ in a boiling water bath was added to the medium. At the end of incubation supernates were collected and the remaining endothelial cells collected after treatment with collagenase. The radioactivity was counted and the results calculated as described. These results represent the means and standard errors of nine replicates obtained in three separate experiments using neutrophils from separate donors. Mean control cytotoxicity by stimulated neutrophils ranged from $17 \%$ to $51 \%$ in these experiments. Abbreviations as in Table III. * $P<0.05$ vs. PMN, one-way analysis of variance.

$\ddagger P<0.01$ vs. $P M N+F M L P$, one-way analysis of variance. $\S P<0.002$ vs. PMN + FMLP + catalase, one-way analysis of variance.

by activated neutrophils $(P<0.001$ vs. activated neutrophils alone, Table V). After inactivation of the enzyme by preincubation with a specific inhibitor (deoxycoformycin), adenosine deaminase did not enhance neutrophil mediated injury $(P$ $<0.001$ vs. activated neutrophils plus adenosine deaminase, Table V). 2-Chloroadenosine, which is poorly metabolized by adenosine deaminase, prevented injury to endothelial cells even in the presence of adenosine deaminase $(P<0.001 \mathrm{vs}$. activated neutrophils plus adenosine deaminase, Table V). 2-Chloroadenosine did not inhibit the enzymatic activity of exogenous adenosine deaminase inasmuch as adenosine was not detected in supernates incubated with both adenosine deaminase and 2chloroadenosine ( $<0.020 \mu \mathrm{M}, n=4$ and 2 , respectively). Neither hypoxanthine $(10 \mu \mathrm{M})$ nor inosine $(10 \mu \mathrm{M})$, the products of adenosine deamination, enhanced endothelial cell injury by activated neutrophils $(36 \pm 7 \%$ and $31 \pm 3 \%$ cytotoxicity, respectively, $P=$ NS vs. stimulated neutrophils alone).

Effect of exogenous adenosine deaminase on endothelial cell toxicity by neutrophils that have not been exposed to a stimulus. Removal of endogenous adenosine permitted unstimulated neutrophils to injure endothelial cells, as reflected by release of ${ }^{51} \mathrm{Cr}(P<0.001$ vs. unstimulated neutrophils alone, Table $\mathrm{V})$. Inactivated enzyme (adenosine deaminase preincubated with deoxycoformycin) did not enhance injury of endothelial cells by unstimulated neutrophils ( $P=$ NS vs. unstimulated neutrophils alone, Table V). Despite removal of endogenously released adenosine, 2-chloroadenosine prevented unstimulated neutro-
Figure 3. (Preceding pages) Photomicrographs of endothelial cell cultures after incubation with unstimulated and stimulated neutrophils in the presence and absence of 2 -chloroadenosine $(10 \mu \mathrm{M})$. Confluent endothelial cells were incubated alone or with neutrophils (10:1 neutrophils/endothelial cells) in Medium 199 for $90 \mathrm{~min}$ at $37^{\circ} \mathrm{C}$. In some wells neutrophils were stimulated with FMLP $(0.1 \mu \mathrm{M})$ in the presence or absence of 2-chloroadenosine $(10 \mu \mathrm{M})$. At the end of the incu- bation period the endothelial cells were washed twice with medium and photographed. $(A)$ Endothelial cells incubated with medium alone. (B) Endothelial cells incubated with unstimulated neutrophils. (C) Endothelial cells incubated with stimulated neutrophils; arrow indicates endothelial cell. $(D)$ Endothelial cells incubated with stimulated neutrophils in the presence of 2-chloroadenosine. 
Table V. Activated Neutrophils Injure Endothelial

Cells: Results Obtained Using Medium 199

\begin{tabular}{lcc}
\hline & \multicolumn{2}{c}{$\%$ cytotoxicity } \\
\cline { 2 - 3 } Condition & Unstimulated & Stimulated \\
\hline PMN & $2 \pm 2$ & $39 \pm 4$ \\
PMN + 2-chloroadenosine & - & $20 \pm 4$ \\
PMN + ADA & $19 \pm 5$ & $69 \pm 3$ \\
PMN + ADA-DCF & $1 \pm 3$ & $33 \pm 5$ \\
PMN + ADA + 2-chloroadenosine & $3 \pm 3$ & $15 \pm 2$ \\
\hline
\end{tabular}

Confluent endothelial cells labeled with ${ }^{51} \mathrm{Cr}$ were incubated with $\mathrm{Me}$ dium 199/BSA (0.2\%) and neutrophils (PMN, $10 \times 10^{6} / \mathrm{ml}, 10: 1$ neutrophils/endothelial cells) without and with FMLP, 2-chloroadenosine, adenosine deaminase (ADA), or adenosine deaminase preincubated with deoxycoformycin (ADA-DCF), as indicated. After 90 min the supernatants and remaining endothelial cells were collected and the radioactivity counted. The data was calculated as described in Methods. These results represent the means and standard errors of 9-18 replicates obtained in three to five separate experiments using neutrophils from different donors and different endothelial cell lines. Mean control cytotoxicity by stimulated neutrophils ranged from $31 \%$ to $43 \%$ in these experiments. Abbreviations as in Table III.

phils from harming endothelial cells $(P<0.005$ vs. unstimulated neutrophils plus adenosine deaminase, Table $\mathrm{V})$. These results show that adenosine also prevented unstimulated neutrophils from injuring endothelial cells.

Adenosine concentrations in supernates of endothelial cell cultures. Both human neutrophils and umbilical vein endothelial cells can release adenosine into the surrounding medium (11, 21). The concentration of endogenously released adenosine reached in suspensions of neutrophils was previously shown to be sufficient to inhibit neutrophil function (11). To assess the concentration of adenosine required for prevention of endothelial cell injury, the concentration of adenosine was determined in supernates of endothelial cells incubated with neutrophils and activated neutrophils. Significant concentrations of adenosine were present in supernates from endothelial cells incubated with medium alone at the beginning and after 30 minutes of incubation $(0.712 \pm 0.078 \mu \mathrm{M}$, mean $\pm \mathrm{SEM}$, and $1.382 \pm 0.135 \mu \mathrm{M}$, respectively, $n=3$ ). Similar concentrations of adenosine were present in supernates of endothelial cells incubated in the presence of either unstimulated or activated neutrophils $(1.064 \pm 0.072 \mu \mathrm{M}$ and $1.301 \pm 0.120 \mu \mathrm{M}$, respectively, $n=4)$.

Source of adenosine in supernatants. The concentration of adenosine present in supernates of endothelial cells before incubation was higher than expected. To determine the source of this adenosine the concentration of adenosine was determined in Medium 199/BSA (0.2\%). Unexpectedly, Medium 199/BSA $(0.2 \%)$ contained a high concentration of adenosine $(0.511 \mu \mathrm{M}$, $n=2$ ). Medium 199 is formulated with adenine and adenine nucleotides and the presence of adenosine is probably due to spontaneous breakdown of adenine nucleotides to adenosine in solution. Endothelial cells further metabolize adenine nucleotides to adenosine present after incubation (22).

Because a high concentration of adenosine was present in Medium 199/BSA (0.2\%), we reassessed the quantity of adenosine released into supernatants by endothelial cells and neutrophils in a medium that did not contain adenine or adenine nucleotides, RPMI 1640/BSA (0.2\%). We also confirmed the effects of 2-chloroadenosine and adenosine deaminase on endothelial cell injury by neutrophils incubated in RPMI 1640/ BSA (0.2\%).

Adenosine concentration in supernates of endothelial cells incubated with RPMI 1640/BSA (0.2\%). RPMI 1640 is not formulated with adenine or adenine nucleotides nor does it contain adenosine ( $<0.020 \mu \mathrm{M}$ in RPMI $1640 / \mathrm{BSA}(0.2 \%), n=2)$. Supernates of endothelial cells incubated in RPMI 1640/BSA $(0.2 \%)$ contained barely detectable concentrations of adenosine before incubation with medium alone $(0.040 \pm 0.015 \mu \mathrm{M}, n=4)$. The adenosine concentration in supernates of endothelial cells doubled after $30 \mathrm{~min}$ of incubation $(0.086 \pm 0.024 \mu \mathrm{M}, n=4)$. Even higher concentrations of adenosine were present in supernates of endothelial cells incubated in the presence of either unstimulated or activated neutrophils $(0.162 \pm 0.019$ and $0.166 \pm 0.050$ $\mu \mathrm{M}$, respectively, $n=4$, Fig. 4).

Effects of 2-chloroadenosine and adenosine deaminase on endothelial cell injury by activated neutrophils in RPMI 1640/ $B S A(0.2 \%)$. As before, neutrophils exposed to FMLP injured endothelial cells $(P<0.001$ vs. unstimulated neutrophils, Table VI). 2-Chloroadenosine (10 $\mu \mathrm{M})$ dramatically diminished injury to endothelial cells by activated neutrophils $(P<0.001$ vs. activated neutrophils, Table VI). Adenosine deaminase enhanced endothelial cell injury by activated neutrophils $(P<0.004$ vs. activated neutrophils, Table VI). Despite the presence of exogenous adenosine deaminase, 2-chloroadenosine inhibited ${ }^{51} \mathrm{Cr}$ release from endothelial cells exposed to activated neutrophils $(P<0.001$ vs. activated neutrophils plus adenosine deaminase, Table VI). These data indicate that exogenous 2-chloroadenosine and endogenously released adenosine diminished injury to endothelial cells by activated neutrophils.

Effects of 2-chloroadenosine and adenosine deaminase on endothelial cell injury, in RPMI 1640/BSA (0.2\%), by neutrophils

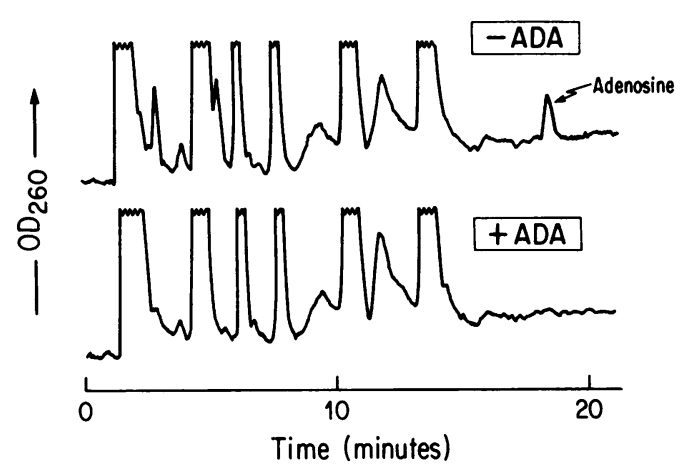

Figure 4. Analysis by reverse-phase high-pressure liquid chromatography of nucleoside concentrations in supernates of endothelial cell cultures incubated with neutrophils $\left(10 \times 10^{6} / \mathrm{ml}\right)$ in the presence (+ADA) and absence (-ADA) of adenosine deaminase $(0.25 \mathrm{IU} / \mathrm{ml})$. Neutrophils were incubated with confluent endothelial cells (10:1 neutrophil/endothelial cells) for $30 \mathrm{~min}$ at $37^{\circ} \mathrm{C}$. The supernatants were collected and spun in a microfuge $(10,000 \mathrm{~g})$ for $5 \mathrm{~min}$ at room temperature to remove neutrophils and particulate debris. Proteins were eliminated by treatment of the supernatants with $2.1 \mathrm{~N}$ PCA followed by neutralization with $2.21 \mathrm{~N} \mathrm{KOH}$. The samples were then applied to a C18 $\mu$ Bondapack column and eluted with a $0-40 \%$ linear gradient (formed over $60 \mathrm{~min}$ ) of $0.01 \mathrm{M}$ ammonium phosphate and methanol with a flow rate of $1.5 \mathrm{ml} / \mathrm{min}$. Shown here are chromatograms of supernatants of endothelial cells incubated with stimulated neutrophils in RPMI. The concentration of adenosine in this experiment was $0.140 \mu \mathrm{M}$, as calculated by comparison with standards. 
Table VI. Activated Neutrophils Injure Endothelial Cells: Results Obtained Using RPMI 1640

\begin{tabular}{lll}
\hline & \multicolumn{2}{l}{$\%$ cytotoxicity } \\
\cline { 2 - 3 } Condition & Unstimulated & Stimulated \\
\hline PMN & $13 \pm 2$ & $42 \pm 3$ \\
PMN + 2-chloroadenosine & - & $15 \pm 3$ \\
PMN + ADA & $19 \pm 3$ & $58 \pm 4$ \\
PMN + ADA + 2-chloroadenosine & $6 \pm 2$ & $11 \pm 3$ \\
\hline
\end{tabular}

Confluent endothelial cells labeled with ${ }^{51} \mathrm{Cr}$ were incubated with RPMI 1640 and neutrophils (PMN, $10 \times 10^{6} / \mathrm{ml}, 10: 1$ neutrophils/endothelial cells) with and without FMLP, 2-chloroadenosine or adenosine deaminase (ADA), as indicated. After 90 min the supernatants and remaining endothelial cells were collected and the radioactivity was counted. The data were calculated as described in Methods. These results represent the means and standard errors of 15-18 replicates obtained in three to six separate experiments using neutrophils from different donors and different endothelial cell lines. Mean control cytotoxicity by stimulated neutrophils ranged from $32 \%$ to $65 \%$ in these experiments. Abbreviations as in Table III.

which have not been exposed to a stimulus. In contrast to the findings of experiments performed in Medium 199/BSA (0.2\%), unstimulated neutrophils incubated in RPMI 1640/BSA (0.2\%) injured endothelial cells $(P<0.001$ vs. endothelial cells alone, Table VI). In the presence of adenosine deaminase unstimulated neutrophils were more injurious to endothelial cells (Table VI), although the difference did not reach statistical significance. Again, even in the presence of adenosine deaminase, 2-chloroadenosine $(10 \mu \mathrm{M})$ decreased endothelial cell injury by neutrophils $(P<0.001$ vs. unstimulated neutrophils plus adenosine deaminase; $P<0.03$ vs. unstimulated neutrophils alone, Table VI).

Neither 2-chloroadenosine, adenosine deaminase, nor any of the other compounds added to the cultures caused increases in release of ${ }^{51} \mathrm{Cr}$ from endothelial cells in the absence of neutrophils. In previous studies we have demonstrated that 2-chloroadenosine, adenosine and adenosine deaminase are neither scavengers nor generators of superoxide anion (11). None of these agents significantly affected ${ }^{51} \mathrm{Cr}$ release from endothelial cells incubated with the cell-free $\mathrm{H}_{2} \mathrm{O}_{2}$-generating system of xanthine-xanthine oxidase (Table VII).

\section{Discussion}

These results indicate that 2-chloroadenosine, a poorly metabolized adenosine analogue, prevents adherence of stimulated neutrophils to endothelial cells and protects the endothelial cells from damage by neutrophils. Moreover, adenosine released into the medium from either endothelial cells or neutrophils prevents both stimulated and unstimulated neutrophils from damaging endothelial cells.

Several laboratories have reported that neutrophils release toxic oxygen metabolites, primarily $\mathrm{H}_{2} \mathrm{O}_{2}$, which injure endothelial cells (5-8). Neither adenosine nor 2-chloroadenosine prevents ${ }^{51} \mathrm{Cr}$ release from endothelial cells caused by the cellfree $\mathrm{H}_{2} \mathrm{O}_{2}$-generating system of xanthine-xanthine oxidase. Nor do either of these compounds act as scavengers of superoxide anion, the presumed precursor of $\mathrm{H}_{2} \mathrm{O}_{2}(11)$. Thus, the ability of adenosine and its analogue to prevent endothelial cell damage by neutrophils must be due to an effect of these compounds on neutrophils.
Table VII. Effect of 2-Chloroadenosine, Adenosine Deaminase, and Adenosine Deaminase Incubated with Deoxycoformycin on

${ }^{51} \mathrm{Cr}$ Release from Endothelial Cells Alone or in the Presence of Xanthine Oxidase $(0.045 \mathrm{U} / \mathrm{ml})$ plus Xanthine $(10 \mu \mathrm{M})$

\begin{tabular}{llll}
\hline & \multicolumn{2}{l}{$\%$ release $( \pm$ SEM) } & \\
\cline { 2 - 4 } Agent & $\begin{array}{l}\text { Endothelial } \\
\text { cells alone }\end{array}$ & $n$ & $\begin{array}{l}\text { Endothelial cells } \\
+ \text { xanthine-xanthine } \\
\text { oxidase }\end{array}$ \\
\hline $\begin{array}{l}\text { Medium } \\
\begin{array}{c}2-\text { Chloroadenosine } \\
(10 \mu \mathrm{M})\end{array}\end{array}$ & $26 \pm 4$ & 3 & $75 \pm 10$ \\
$\begin{array}{c}\text { Adenosine deaminase } \\
(0.25 \mathrm{IU} / \mathrm{ml})\end{array}$ & $26 \pm 1$ & 3 & $78 \pm 1$ \\
$\begin{array}{c}\text { Adenosine deaminase } \\
+ \text { deoxycoformycin }\end{array}$ & $31 \pm 1$ & 3 & $83 \pm 5$ \\
\hline
\end{tabular}

Confluent cultures of ${ }^{51} \mathrm{Cr}$-labeled endothelial cells were incubated in medium alone or with 2-chloroadenosine, adenosine deaminase, or adenosine deaminase preincubated with deoxycoformycin $(1 \mu \mathrm{M}$ final concentration) for $90 \mathrm{~min}$ at $37^{\circ} \mathrm{C}$. Medium $199 / 0.2 \%$ BSA was the culture medium in experiments performed on endothelial cells alone. RPMI 1640 was the culture medium for those experiments in which the effect was assessed of agents on xanthine-xanthine oxidase induced release of ${ }^{51} \mathrm{Cr}$. For these experiments confluent endothelial cells labeled with ${ }^{51} \mathrm{Cr}$ were incubated with xanthine $(10 \mu \mathrm{M})$ plus xanthine oxidase $(0.045 \mathrm{U} / \mathrm{ml})$ for $15 \mathrm{~min}$ at $37^{\circ} \mathrm{C}$. Medium 199 could not be used in those experiments involving xanthine oxidase because the high concentrations of hypoxanthine present in this medium led to complete destruction of all endothelial cells at time points as early as 15 min of incubation. Supernatants and cells were collected and counted and $\%{ }^{51} \mathrm{Cr}$ release calculated as described. These results are similar to those found in two other experiments.

Whether activated neutrophils can indeed injure endothelial cells or simply cause their detachment by release of proteolytic enzymes remains controversial (5-9). In sharp contrast to our findings, Varani et al. (23) have reported that, although a variety of agents stimulated neutrophils to injure bovine pulmonary artery endothelial cells, FMLP did not. Fehr et al. (24) have reported that FMLP stimulates neither adherence of neutrophils to endothelial cells nor neutrophil-mediated injury to endothelial cells. Another recent report indicates that only neutrophils "primed" with bacterial lipopolysaccharide can injure human microvascular endothelial cells upon stimulation with FMLP (25). Although we cannot identify with certainty the cause(s) for these discrepancies, the conflicting findings reported from various laboratories most probably result from the disparate cultures and conditions used in these experiments. Depending on their source (human umbilical vein, human adipose tissue microvessels, bovine aorta, or bovine pulmonary artery) endothelial cells vary in their susceptibility to lysis by activated neutrophils (7). When serum is added to endothelial cell cultures exposed to activated neutrophils, scavengers of $\mathrm{H}_{2} \mathrm{O}_{2}$ may prevent damage (26). Similarly, serum decreases the neutrophil-mediated detachment from substrates of endothelial cells because of serum antiproteases (9). The failure of Fehr et al. (24) to find that FMLPstimulated neutrophils injured endothelial cells is probably due to their use of heparinized, heated plasma in which adherence proteins may be altered. Endothelial cells protect themselves from the deleterious effects of $\mathrm{H}_{2} \mathrm{O}_{2}$ via the glutathione redox cycle (27). Since reduced glutathione present in tissue culture medium may raise intracellular glutathione concentrations (28), the high concentrations of reduced glutathione in some tissue 
culture media (as high as $15 \mathrm{mg} /$ liter in Waymouth's medium used by some investigators $(9,18,27)$ and $1 \mathrm{mg} /$ liter in RPMI 1640) may protect endothelial cells from oxidative damage due to stimulated neutrophils. Further, different tissue culture media contain different concentrations of vitamins, amino acids, and other nutrients (e.g., purine nucleotides and bases in Medium 199) which may also influence the ability of endothelial cells to withstand attack by activated neutrophils. Lastly, the method by which neutrophils are isolated from whole blood may enhance the ability of these cells to injure cultured endothelial cells (24, 29). Thus, our demonstration that neutrophils stimulated by FMLP injured human umbilical vein endothelial cells differs from previous reports because of the source or preparation of the neutrophils and endothelial cells, the absence of serum or anticoagulated plasma, or use of different tissue culture media in our assay system.

We found that 2-chloroadenosine inhibited adherence of stimulated human neutrophils to human umbilical vein endothelial cells. In contrast, Pearson et al. (30) reported that adenosine enhanced adherence of unstimulated porcine neutrophils to cultured porcine endothelial cells. The cause of this discrepancy is, again, not absolutely identifiable but is most likely a result of the different species of origin of the neutrophils studied. Similar species differences have been well documented for the effects of adenosine on stimulated mast cell or basophil function (31-34). Our observation that 2-chloroadenosine inhibits stimulated neutrophil adherence to endothelial cells is important because neutrophil adherence is a critical first step for both endothelial cell injury $(2,5,18,35)$ and emigration of neutrophils from the vasculature (36).

We, and subsequently others, have shown that adenosine and adenosine analogues inhibit generation of toxic oxygen metabolites by stimulated neutrophils via engagement of adenosine $A_{2}$ receptors on neutrophils (11-14). Once adherent, neutrophils may injure endothelial cells by generation of toxic oxygen products (5-8). It is, therefore, probable that the protective effects of adenosine and 2-chloroadenosine are due to the interaction of adenosine and 2-chloroadenosine with the specific adenosine receptor on neutrophils. However, engagement of neutrophil adenosine receptors does not completely inhibit either release of toxic oxygen metabolites from activated neutrophils or adherence of neutrophils to endothelial cells (11-14). Thus, as we have shown here, 2-chloroadenosine at a concentration that maximally inhibits neutrophil function $(10 \mu \mathrm{M}, 11-14)$ does not completely inhibit endothelial cell injury by neutrophils.

Supernatants of endothelial cells incubated with and without neutrophils in Medium 199 contained significantly more adenosine than supernatants of endothelial cells incubated in identical conditions in RPMI 1640. The disparity between the adenosine concentrations in supernatants incubated with these two media is due to the presence of adenine nucleotides in Medium 199 which must break down to adenosine during storage. Because of the presence of adenosine, Medium 199 is probably not suitable for use in experiments designed to determine the effects of adenosine or its analogues. Endothelial cells also actively metabolize adenine nucleotides to adenosine thus contributing to the adenosine present in the supernatants of endothelial cells incubated with Medium 199 (22). In contrast, RPMI 1640 is not formulated with adenine nucleotides and contains no adenosine.

Depletion of adenosine from Medium 199 permitted unstimulated neutrophils to provoke a sixfold increase in endo- thelial cell injury whereas elimination of the smaller amounts of adenosine generated by the cells in RPMI 1640 allowed a smaller increment in endothelial cell injury by unstimulated neutrophils. Indeed, endothelial cells were injured by unstimulated neutrophils in the presence of the low concentrations of adenosine in RPMI 1640, and the increment in endothelial cell injury was significantly reversed by addition of 2-chloroadenosine to the medium. It may be no accident that the concentration of adenosine in plasma is severalfold higher than that in RPMI 1640/BSA (20); indeed, plasma adenosine may moderate the effects of neutrophils on otherwise healthy tissues.

The uncontrolled or inappropriate activation of neutrophils has been implicated in the pathogenesis of a variety of human diseases. Persuasive evidence has been presented that activated neutrophils contribute to the adult respiratory distress syndrome by release of toxic oxygen metabolites that damage the pulmonary microvasculature $(37,38)$. Activated neutrophils may also be responsible for damage to atherosclerotic vessels (39), ischemic cardiac muscle (40-42), as well as vascular damage in a variety of vasculitides $(43,44)$. Recent studies suggest that adenosine is specifically released from endothelial cells in response to hydrogen peroxide (21). Cardiac muscle also releases adenosine after ischemia or injury $(45,46)$. Endogenous adenosine, released by damaged cells and tissues, or pharmacologically active adenosine analogues may prevent vascular injury by neutrophils activated in the course of thrombosis or inflammation.

\section{Acknowledgments}

The authors thank Stephen Buck, Paul Cristello, and Wendy Lovenvirth for their technical assistance without which this project could not have been completed.

Dr. Cronstein is a fellow of the Arthritis Foundation and is the recipient of Clinical Investigator Award K11AM0149001 from the National Institutes of Health; Dr. Levin is the recipient of Clinical Investigator Award K08HL00748 from the National Institutes of Health. This work was supported by grants from the New York Arthritis Foundation, the S.L.E. Foundation, the American Lung Association, the Rosenbloom Foundation, Johnson \& Johnson, the Dana Trust, the Evans Foundation and grants AI10343, AM1 1949, HL19721, and AI17365 from the National Institutes of Health.

\section{References}

1. Smolen, J. E., H. M. Korchak, and G. Weissmann. 1982. Stimulus response coupling in neutrophils. Trends Pharmacol. Sci. 3:483-487.

2. Boogaerts, M. A., O. Yamada, H. S. Jacob, and C. F. Moldow. 1982. Enhancement of granulocyte-endothelial cell adherence and granulocyte-induced cytotoxicity by platelet release products. Proc. Natl. Acad. Sci. USA. 79:7019-7023.

3. Tonnesen, M. G., L. A. Smedly, and P. M. Henson. 1984. Neutrophil-endothelial cell interactions. Modulation of neutrophil adhesiveness induced by complement fragments C5a and C5a des arg and formyl-methionyl-leucyl-phenylalanine in vitro. J. Clin. Invest. 74:15811592.

4. Charo, I. F., C. Yuen, and I. M. Goldstein. 1985. Adherence of human polymorphonuclear leukocytes to endothelial monolayers: effects of temperature, divalent cations, and chemotactic factors on the strength of adherence measured with a new centrifugation assay. Blood. 65:473479.

5. Sacks, T., C. F. Moldow, P. R. Craddock, T. K. Bowers, and H. S. Jacob. 1978. Oxygen radicals mediate endothelial cell damage by complement-stimulated granulocytes. J. Clin. Invest. 61:1161-1167.

6. Weiss, S. J., J. Young, A. F. LoBuglio, and A. Slivka. 1981. Role of hydrogen peroxide in neutrophil-mediated destruction of cultured endothelial cells. J. Clin. Invest. 68:714-721. 
7. Suttorp, N., and L. M. Simon. 1982. Lung cell oxidant injury. Enhancement of polymorphonuclear leukocyte-mediated cytotoxicity in lung cells exposed to sustained in vitro hyperoxia. J. Clin. Invest. 70: 342-350.

8. Niwa, Y., S. Miyake, T. Sakane, M. Shingu, and M. Yokoyama. 1982. Auto-oxidative damage in Behcet's disease: endothelial cell damage following the elevated oxygen radicals generated by stimulated neutrophils. Clin. Exp. Immunol. 49:247-255.

9. Harlan, J. M., P. D. Killen, L. A. Harker, G. E. Striker, and D. G. Wright. 1981. Neutrophil-mediated endothelial injury in vitro. Mechanisms of cell detachment. J. Clin. Invest. 68:1394-1403.

10. Berne, R. M., R. M. Knabb, S. W. Ely, and R. Rubio. 1982. Adenosine in the local regulation of blood flow: a brief overview. Fed. Proc. 42:3136-3142.

11. Cronstein, B. N., S. B. Kramer, G. Weissmann, and R. Hirschhorn. 1983. Adenosine: a physiological modulator of superoxide anion generation by human neutrophils. J. Exp. Med. 158:1160-1177.

12. Cronstein, B. N., E. D. Rosenstein, S. B. Kramer, G. Weissmann, and R. Hirschhorn. 1985. Adenosine: a physiologic modulator of superoxide anion generation by human neutrophils. Adenosine acts via an $\mathrm{A}_{2}$ receptor on human neutrophils. J. Immunol. 135:1366-1371.

13. Cronstein, B. N., S. M. Kubersky, G. Weissmann, and R. Hirschhorn. 1985. Release of superoxide anion $\left(\mathrm{O}_{2}^{-}\right)$and hydrogen peroxide $\left(\mathrm{H}_{2} \mathrm{O}_{2}\right)$ from neutrophils by immune complexes cannot be inhibited by engagement of adenosine receptors. Clin. Res. 33:337A. (Abstr.)

14. Roberts, P. A., A. C. Newby, M. B. Hallett, and A. K. Campbell. 1985. Inhibition by adenosine of reactive oxygen metabolite production by human polymorphonuclear leucocytes. Biochem. J. 227:669-674.

15. Jaffe, E. A., R. L. Nachman, C. G. Becker, and C. R. Minick. 1973. Culture of human endothelial cells derived from umbilical veins: identification by morphologic and immunologic criteria. J. Clin. Invest. 52:2745-2756.

16. Boyum, A. 1968. Isolation of mononuclear cells and granulocytes from human blood. Scand. J. Clin. Lab Invest. 21(Suppl.):77-89.

17. Gallin, J. I., R. A. Clark, and H. R. Kimball. 1973. Granulocyte chemotaxis: an improved in vitro assay employing ${ }^{51} \mathrm{Cr}$-labeled granulocytes. J. Immunol. 110:233-240.

18. Diener, A. M., P. G. Beatty, H. D. Ochs, and J. M. Harlan. 1985. The role of neutrophil membrane glycoprotein 150 (gp-150) in neutrophilmediated endothelial cell injury in vitro. J. Immunol. 135:537-543.

19. Walther, B. T., R. Ohman, and S. Roseman. 1973. A quantitative assay for intercellular adhesion. Proc. Natl. Acad. Sci. USA. 70:15691573.

20. Hirschhorn, R., V. Roegner-Maniscalco, L. Kuritsky, and F. S. Rosen. 1981. Bone marrow transplantation only partially restores purine metabolites to normal in adenosine deaminase-deficient patients. J. Clin. Invest. 68:1387-1393.

21. Ager, A., and J. L. Gordon. Differential effects of hydrogen peroxide on indices of endothelial cell function. J. Exp. Med. 159:592-603.

22. Pearson, J. D., and J. L. Gordon. 1979. Vascular endothelial and smooth muscle cells in culture selectively release adenine nucleotides. Nature (Lond.). 281:384-386.

23. Varani, J., S. E. G. Fligiel, G. O. Till, R. G. Kunkel, U. S. Ryan, and P. A. Ward. 1985. Pulmonary endothelial cell killing by human neutrophils. Possible involvement of hydroxyl radical. Lab. Invest. 53: 656-663.

24. Fehr, J. S., R. Moser, D. Leppert, and P. Groscurth. 1985. Antiadhesive properties of biological surfaces are protective against stimulated granulocytes. J. Clin. Invest. 76:535-542.

25. Smedly, L. A., M. G. Tonnesen, R. A. Sandhaus, C. Haslett, L. A. Guthrie, R. B. Johnston, Jr., P. M. Henson, and G. S. Worthen. 1986. Neutrophil-mediated injury to endothelial cells. Enhancement by endotoxin and essential role of neutrophil elastase. J. Clin. Invest. 77: 1233-1243.

26. Bishop, C. T., Z. Mirza, J. D. Crapo, and B. A. Freeman. 1985. Free radical damage to porcine aortic endothelial cells and lung fibroblasts: modulation by culture conditions. In Vitro (Rockville). 21:229-236.

27. Harlan, J. M., J. D. Levine, K. S. Callahan, B. R. Schwartz, and
L. A. Harker. 1984. Glutathione redox cycle protects cultured endothelial cells against lysis by extracellularly generated hydrogen peroxide. J. Clin. Invest. 73:706-713.

28. Whikehart, D. R., and H. F. Edelhauser. 1978. Glutathione in rabbit corneal endothelia: the effects of selected perfusion fluids. Invest. Ophthalmol. Visual Sci. 17:455-464.

29. Haslett, C., L. A. Guthrie, M. M. Kopaniak, R. B. Johnston, Jr., and P. M. Henson. 1985. Modulation of multiple neutrophil functions by preparative methods or trace concentrations of bacterial lipopolysaccharide. Am. J. Pathol. 119:101-110.

30. Pearson, J. D., J. S. Carleton, J. E. Beesley, A. Hutchings, and J. L. Gordon. 1979. Granulocyte adhesion to endothelium in culture. J. Cell. Sci. 38:225-235.

31. Marone, G., S. R. Findlay, and L. M. Lichtenstein. 1979. Adenosine receptor on human basophils: modulation of histamine release. $J$. Immunol. 123:1473-1477.

32. Church, M. K., S. T. Holgate, and P. J. Hughes. 1983. Adenosine inhibits and potentiates IgE-dependent histamine release from human basophils by an $\mathrm{A}_{2}$-receptor mediated mechanism. Br. J. Pharmacol. 80: 719-726.

33. Burt, D. S., and D. R. Stanworth. 1983. The effect of ribose and purine modified adenosine analogues on the secretion of histamine from rat mast cells induced by ionophore A23187. Biochem. Pharmacol. 32: 2729-2732.

34. Marquardt, D. L., L. L. Walker, and S. I. Wasserman. 1984. Adenosine receptors on mouse bone marrow-derived mast cells: functional significance and regulation by aminophylline. J. Immunol. 133: 932-937.

35. Shasby, D. M., S. S. Shasby, and M. J. Peach. 1983. Granulocytes and phorbol myristate acetate increase permeability to albumin of cultured endothelial monolayers and isolated perfused lungs. Role of oxygen radicals and granulocyte adherence. Am. Rev. Respir. Dis. 127:72-76.

36. Harlan, J. L. 1985. Leukocyte-endothelial interactions. Blood. 65:513-525.

37. Johnson, K. J., and P. A. Ward. 1981. Role of oxygen metabolites in immune complex injury of lung. J. Immunol. 126:2365-2369.

38. Shasby, D. M., K. M. Vanbenthuysen, R. M. Tate, S. S. Shasby, I. McMurtry, and J. E. Repine. 1982. Granulocytes mediate acute edematous lung injury in rabbits and in isolated rabbit lungs perfused with phorbol myristate acetate: role of oxygen radicals. Am. Rev. Respir. Dis. 125:443-447.

39. Kohchi, K., S. Takebayashi, T. Hiroki, and M. Nobuyoshi. 1985. Significance of adventitial inflammation of the coronary artery in patients with unstable angina: results at autopsy. Circulation. 71:709-716.

40. Mullane, K. M., N. Read, J. A. Salmon, and S. Moncada. 1984. Role of leukocytes in acute myocardial infarction in anesthetized dogs: relationship to myocardial salvage by antiinflammatory drugs. J. Pharmacol. Exp. Ther. 228:510-522.

41. Hartmann, J. R., J. A. Robinson, and R. M. Gunnar. 1977. Chemotactic activity in the coronary sinus after experimental myocardial infarction: effects of pharmacologic interventions on ischemic injury. Am. J. Cardiol. 40:550-555.

42. Romson, J. L., B. G. Hook, S. L. Kunkel, G. D. Abrams, M. A. Schork, and B. R. Lucchesi. 1983. Reduction of the extent of ischemic myocardial injury by neutrophil depletion in the dog. Circulation. 67: 1016-1023.

43. Cochrane, C. G., W. O. Weigle, and F. J. Dixon. 1959. The role of polymorphonuclear leukocytes in the initiation and cessation of the Arthus vasculitis. J. Exp. Med. 110:481-494.

44. Humphrey, J. H. 1955. The mechanism of Arthus reactions. I. The role of polymorphonuclear leucocytes and other factors in reverse passive Arthus reactions in rabbits. Br. J. Exp. Pathol. 36:268-282.

45. Fox, A. C., G. E. Reed, E. Glassman, A. J. Koltman, and B. Silk. 1974. Release of adenosine from human hearts during angina induced by rapid atrial pacing. J. Clin. Invest. 53:1447-1457.

46. Fox, A. C., G. E. Reed, H. Meilman, and B. B. Silk. 1979. Release of nucleosides from canine and human hearts as an index of prior ischemia. Am. J. Cardiol. 43:52-58. 